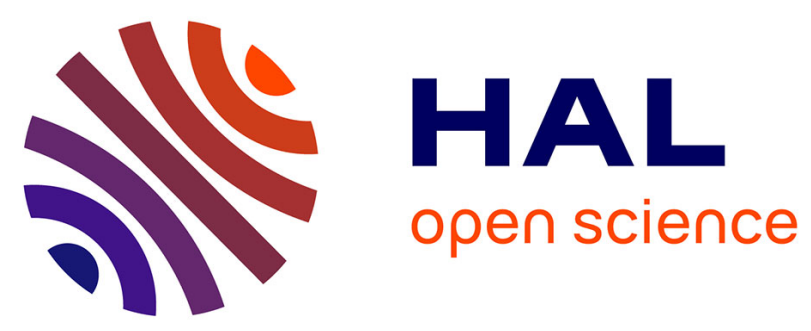

\title{
Population genetic structure of the endangered crayfish Austropotamobius pallipes in France based on microsatellite variation: biogeographical inferences and conservation implications
}

\author{
N. Gouin, F. Grandjean, C. Souty-Grosset
}

\section{To cite this version:}

N. Gouin, F. Grandjean, C. Souty-Grosset. Population genetic structure of the endangered crayfish Austropotamobius pallipes in France based on microsatellite variation: biogeographical inferences and conservation implications. Freshwater Biology, 2006, 51, pp.1369-1387. 10.1111/j.13652427.2006.01570.x . hal-00084210

\author{
HAL Id: hal-00084210 \\ https://hal.science/hal-00084210
}

Submitted on 13 Jul 2006

HAL is a multi-disciplinary open access archive for the deposit and dissemination of scientific research documents, whether they are published or not. The documents may come from teaching and research institutions in France or abroad, or from public or private research centers.
L'archive ouverte pluridisciplinaire HAL, est destinée au dépôt et à la diffusion de documents scientifiques de niveau recherche, publiés ou non, émanant des établissements d'enseignement et de recherche français ou étrangers, des laboratoires publics ou privés. 


\title{
APPLIED ISSUES
}

\section{Population genetic structure of the endangered crayfish Austropotamobius pallipes in France based on microsatellite variation: biogeographical inferences and conservation implications}

\author{
N. GOUIN, F. GRANDJEAN AND C. SOUTY-GROSSET \\ Laboratoire de Génétique et Biologie des Populations de Crustacés, UMR CNRS, Université de Poitiers, Poitiers cedex, France
}

\begin{abstract}
SUMMARY
1. One important goal in conservation biology is to characterise evolutionary lineages within endangered species before management decisions are taken. Here, we assess population differentiation in the freshwater crayfish Austropotamobius pallipes, an endangered species endemic to western Europe and provide valuable information for the conservation of French populations.

2. Analysis of five microsatellite loci in 44 populations revealed very different within population levels of genetic diversity $\left(0.000<H_{0}<0.564\right)$. Two groups, corresponding to northern and southern French populations, showed a high degree of genetic differentiation in both allele frequencies and allele sizes. Comparison of these results with previous studies of $A$. pallipes strongly suggests that the divergence between northern and southern populations could have occurred during the last glaciation period of the Pleistocene from one Atlantic and one Mediterranean refuge.

3. Evidence for genetic admixture between these two lineages was revealed by correspondence analyses in southern populations, probably as the result of artificial translocations.

4. French populations appeared significantly differentiated among the different river drainages and were highly structured within rivers. The impact of population size, population bottlenecks and founder events on the population genetic differentiation are discussed.

5. Based on these results, we propose the designation of two evolutionarily significant units for A. pallipes in France. Our data also support the maintenance of separate demographic management strategies for crayfish inhabiting different river systems. However, genetic analyses will have to be combined with demographic and ecological data for sustainable conservation programmes.
\end{abstract}

Keywords: Austropotamobius pallipes, conservation genetics, evolutionarily significant unit, microsatellites, secondary contact

Correspondence: N. Gouin, Department of Genetics,

Southwest Foundation for Biomedical Research, PO Box 760549,

San Antonio, TX 78245-0549, U.S.A.

E-mail: ngouin@darwin.sfbr.org

\section{Introduction}

Maintaining the evolutionary potential of endangered species is a fundamental goal in conservation biology. In 1986, Ryder developed the concept of the evolutionarily significant unit (ESU), characterised by 
populations harbouring multiple concordant characters based on ecological, ethological, biogeographical and morphological data (Ryder, 1986). Since then, various definitions have been formulated and widely discussed (reviewed in Fraser \& Bernatchez, 2001). The most significant and recent disagreement focused on the importance of including ecological data when defining ESUs. In fact, Crandall et al. (2000) argued that the exclusive use of neutral genetic markers did not place enough emphasis on the potential of species to maximise evolutionary success through the maintenance of adaptive diversity. However, in an effort to unify the various concepts of ESU, Fraser \& Bernatchez (2001) concluded that each approach had its strengths and weaknesses under different circumstances and thus could be used alone or in combination depending on the situation.

The white-clawed crayfish, Austropotamobius pallipes (Lereboullet 1858), is endemic to Western Europe. This species is experiencing a drastic decline in natural populations that has been attributed to habitat loss, water pollution and the effects of competition and diseases from introduced crayfish species (Changeux, 2003). Austropotamobius pallipes has been listed in the red book of endangered species since 1983 (Baillie \& Groombridge, 1996) and listed under Annex 2 of the EU Habitats Directive as a species requiring special conservation measures. Because French A pallipes populations had not received much detailed study, the decision was made to employ a molecular genetic approach in order to evaluate the distribution of the genetic variation in the French stock. Such an approach is particularly appropriate for species suffering a rapid population decline because it provides important information for management strategies if such actions need to be employed (Hedrick, 2000). Furthermore, according to Moritz (1994), the accumulation of genetic differences through reproductive isolation is a critical factor to consider in defining evolutionary lineages for conservation. He therefore proposed to define ESUs as groups of populations that are reciprocally monophyletic for mitochondrial DNA alleles and show significant divergence of allele frequencies at nuclear loci.

Mitochondrial DNA variation in French populations of A. pallipes has been analysed by Grandjean \& SoutyGrosset (2000). Using restriction fragment length polymorphism (RFLP) analysis in 21 populations, they identified two lineages of mtDNA haplotypes showing reciprocal monophily and separating northern from southern French populations. According to the definition of Moritz (1994), polymorphism at nuclear loci has to be investigated in order to support the hypothesis of two ESUs in A. pallipes in France. The random amplified polymorphic DNA (RAPD) method was used in a study of 17 French populations (Gouin et al., 2001). As described with mtDNA by Grandjean \& Souty-Grosset (2000), RAPDs revealed significant genetic differentiation between northern and southern populations. In light of this result, the hypothesis of deep divergence between these two groups of populations, probably resulting from an ancient separation during the glaciations of the Pleistocene, was proposed. However, four populations sampled in eastern France appeared genetically differentiated from the northern and southern ones, suggesting the possible existence of a third refuge area during the Pleistocene and therefore of a potential third ESU. In this context and due to the lack of statistical power of RAPD analyses, the use of additional nuclear markers was needed to clarify the genetic structure between French populations of $A$. pallipes. Microsatellite markers have recently been isolated for this species (Gouin, Grandjean \& SoutyGrosset, 2000; Gouin et al., 2002). These codominant genetic markers are highly polymorphic, more informative than dominant markers such as RAPDs and now constitute the most commonly used method to assess population genetic structure on a fine scale. Moreover, the two studies described above were based on a limited number of populations and important French river basins were not represented (the Adour and the Seine) or poorly represented (only one population from the Garonne). Therefore, a more extensive sampling effort was needed in order to get a better picture of the genetic differentiation in the French stock.

The objective of this study was to examine the genetic variation at five microsatellite loci within French populations of $A$. pallipes and to analyse its distribution in a large sample representative of the distribution of the species in France. Our main focus was to discuss the relevance of these results for the conservation of the white-clawed crayfish.

\section{Methods}

Sample collection

Austropotamobius pallipes is still widespread in France, but it is now confined largely to headwater river 
systems (Changeux, 2003). Most of populations are located in the southern part of France, the northern part harbouring only scattered populations. In order to cover most of the range of A. pallipes, a total of 43 populations were sampled in the main French river basins between 1999 and 2001 (Fig. 1; Table 1). One additional population was sampled in Germany (Fribourg) close to the French border. One pereiopod of the fourth pair was taken from each individual and stored in pure ethanol until DNA extraction. The number of individuals per sample is listed in Table 1.

\section{Microsatellite analysis}

Gouin et al. (2000) identified four polymorphic microsatellites in A. pallipes: Ap2, Ap3, Ap5 and Ap6. More recently, Gouin et al. (2002) characterised an additional locus $A p 7$ in a French population and designed a new forward primer for $A p 5$ to facilitate its analysis. These five microsatellites were used in the present study to assess genetic variation in A. pallipes. All experimental procedures for DNA extraction, microsatellite amplification and genotyping were identical to those described in Gouin et al. (2002).

Locus Ap5 generated alleles with complex patterns of amplification having many stutter bands. For this reason, each individual was scored twice independently at this locus, and reamplified in case of discordance. Individuals were then rescored and any ambiguous genotype was blanked.

\section{Statistical analysis}

The average number of alleles per locus $(A)$, the observed heterozygosity $\left(H_{\mathrm{O}}\right)$ and the expected heterozygosity $\left(H_{\mathrm{E}}\right)$ were computed with GENETIX 4.05

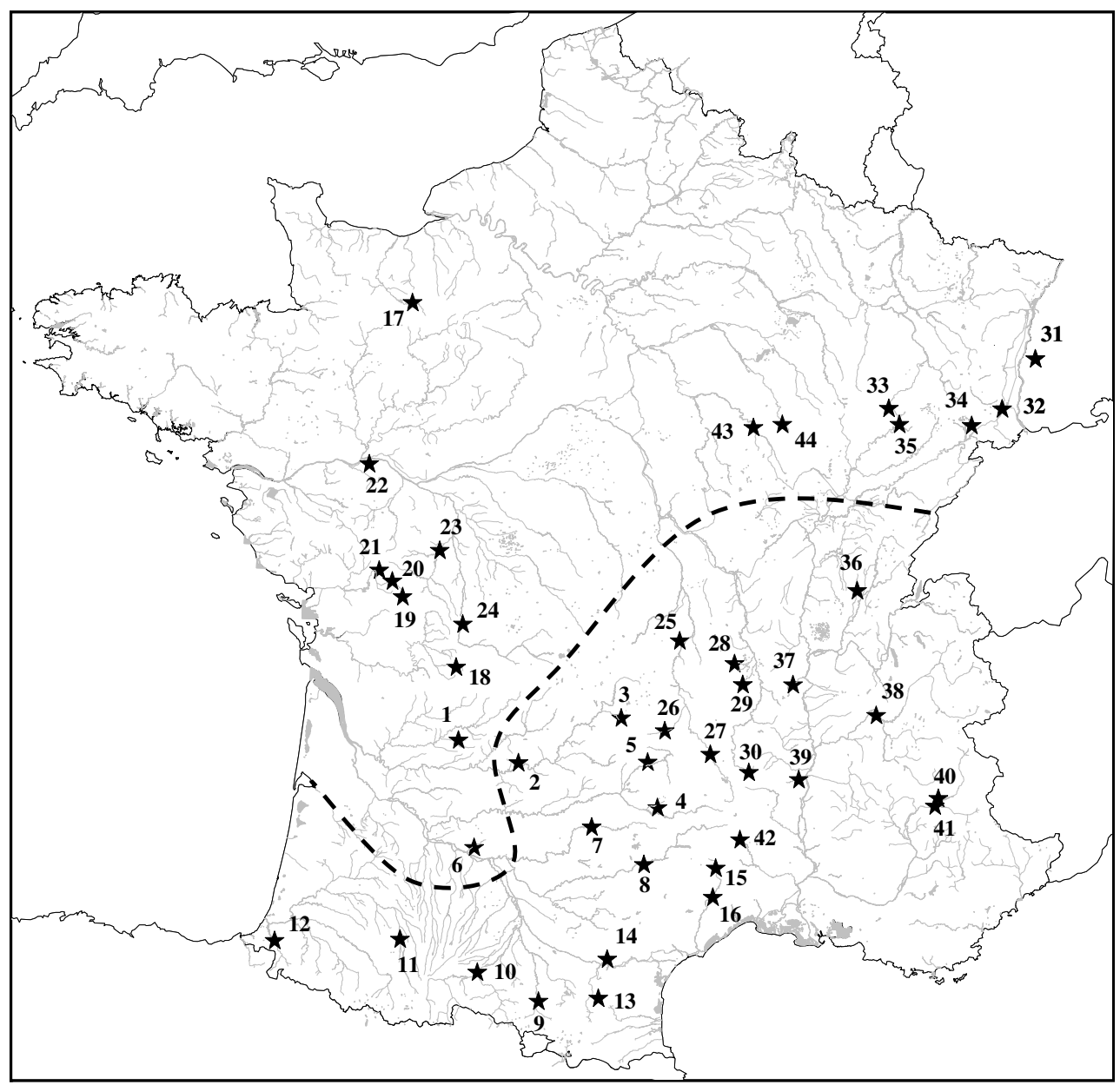

Fig. 1 Geographical position of the 44 French populations of A. pallipes sampled for this study. The dashed line represents the boundary between northern (NJ group I) and southern (NJ group II) populations. 
1372 N. Gouin et al.

Table 1 Description of the populations sampled for this study (name, river basin, code used in the analyses, sample size $=N$ ) and summary statistics for the five microsatellites analysed

\begin{tabular}{|c|c|c|c|c|c|c|}
\hline Population & $\begin{array}{l}\text { Major } \\
\text { drainage }\end{array}$ & Code & $N$ & $A$ & $H_{\mathrm{O}}$ & $H_{\mathrm{E}}$ \\
\hline Le Serre & \multirow[t]{10}{*}{ Garonne } & GAR-1 & 20 & 2.0 & 0.223 & 0.207 \\
\hline Saint Romain & & GAR-2 & 12 & 3.0 & 0.583 & 0.564 \\
\hline Rau le Mardaret & & GAR-3 & 11 & 1.4 & 0.058 & 0.056 \\
\hline Boralde d'Aubrac & & GAR-4 & 20 & 1.4 & 0.120 & 0.117 \\
\hline Pierrefont & & GAR-5 & 10 & 1.6 & 0.147 & 0.199 \\
\hline Brezegues & & GAR-6 & 11 & 2.0 & 0.365 & 0.335 \\
\hline Combe Nègre & & GAR-7 & 20 & 1.2 & 0.100 & 0.100 \\
\hline Lavandou & & GAR-8 & 19 & 1.4 & 0.044 & 0.075 \\
\hline Artix ${ }^{*+}$ & & GAR-9 & 14 & 3.0 & 0.400 & 0.468 \\
\hline Belbèze & & GAR-10 & 5 & 2.4 & 0.400 & 0.347 \\
\hline Louet & \multirow[t]{2}{*}{ Adour } & ADO-11 & 19 & 2.6 & 0.442 & 0.456 \\
\hline Lys & & ADO-12 & 18 & 2.4 & 0.287 & 0.296 \\
\hline Laurio* & \multirow[t]{2}{*}{ Aude } & AUD-13 & 12 & 1.0 & 0.000 & 0.000 \\
\hline Serremijannes* & & AUD-14 & 10 & 1.2 & 0.022 & 0.022 \\
\hline Le Garrel & \multirow[t]{2}{*}{ Hérault } & HER-15 & 7 & 1.4 & 0.040 & 0.057 \\
\hline Combe Bonne* & & HER-16 & 18 & 1.2 & 0.023 & 0.023 \\
\hline Val Renard*+ & Orne & ORN-17 & 12 & 1.2 & 0.073 & 0.104 \\
\hline Fontaine St Pierre ${ }^{*^{+}}$ & Charente & CHA-18 & 11 & 1.6 & 0.200 & 0.205 \\
\hline Renardières & \multirow[t]{3}{*}{ Sèvre Niortaise } & SEV-19 & 19 & 2.0 & 0.284 & 0.278 \\
\hline Marcusson & & SEV-20 & 24 & 1.8 & 0.275 & 0.276 \\
\hline Breuil & & SEV-21 & 20 & 2.6 & 0.334 & 0.349 \\
\hline Brocard & \multirow[t]{9}{*}{ Loire } & LOI-22 & 30 & 2.4 & 0.329 & 0.357 \\
\hline Macre & & LOI-23 & 22 & 2.0 & 0.313 & 0.336 \\
\hline Crochatière $^{*+}$ & & LOI-24 & 19 & 1.8 & 0.282 & 0.248 \\
\hline Fourneaux & & LOI-25 & 7 & 1.4 & 0.190 & 0.159 \\
\hline Alagnon & & LOI-26 & 10 & 1.6 & 0.182 & 0.155 \\
\hline Besque $^{+}$ & & LOI-27 & 20 & 1.6 & 0.133 & 0.172 \\
\hline Périchon* & & LOI-28 & 14 & 1.8 & 0.157 & 0.200 \\
\hline Curraize $^{*}$ & & LOI-29 & 14 & 2.0 & 0.222 & 0.265 \\
\hline Mejeanne* & & LOI-30 & 20 & 1.6 & 0.170 & 0.170 \\
\hline Fribourg $(\mathrm{DE})^{+}$ & \multirow[t]{2}{*}{ Rhin } & RHI-31 & 9 & 1.6 & 0.208 & 0.207 \\
\hline La Lucelle ${ }^{*+}$ & & RHI-32 & 10 & 1.8 & 0.340 & 0.332 \\
\hline Ru des menottes & \multirow[t]{10}{*}{ Rhône } & RHO-33 & 16 & 2.2 & 0.400 & 0.412 \\
\hline Madeleine $^{\dagger}$ & & RHO-34 & 12 & 2.0 & 0.317 & 0.299 \\
\hline Le Rupt ${ }^{+}$ & & RHO-35 & 24 & 1.8 & 0.258 & 0.272 \\
\hline Sélignac $^{\dagger}$ & & RHO-36 & 16 & 2.8 & 0.262 & 0.345 \\
\hline Mornante & & RHO-37 & 10 & 1.8 & 0.180 & 0.181 \\
\hline Isère $^{+}$ & & RHO-38 & 15 & 2.2 & 0.188 & 0.216 \\
\hline Mezayon & & RHO-39 & 18 & 2.6 & 0.300 & 0.289 \\
\hline Serre-Ponçon & & RHO-40 & 20 & 1.6 & 0.183 & 0.208 \\
\hline Turrelet & & RHO-41 & 20 & 2.0 & 0.270 & 0.283 \\
\hline Gardon St Martin* ${ }^{{ }^{+}}$ & & RHO-42 & 8 & 1.4 & 0.111 & 0.173 \\
\hline Ru du Verpan & \multirow[t]{2}{*}{ Seine } & SEI-43 & 19 & 2.0 & 0.233 & 0.225 \\
\hline Seine & & SEI-44 & 10 & 1.6 & 0.180 & 0.289 \\
\hline
\end{tabular}

Significant departures from Hardy-Weinberg equilibrium prior to the sequential Bonferroni corrections are reported in bold.

*Populations analysed by RFLP mtDNA (Grandjean \& Souty-Grosset, 2000).

${ }^{\dagger}$ Populations analysed by RAPD (Gouin et al., 2001).

$A$, mean number of alleles per locus; $H_{\mathrm{O}}$, observed heterozygosity; $H_{\mathrm{E}}$, expected heterozygosity).

(Belkhir et al., 1996-2004). Unbiased expected heterozygosity (Nei, 1978) was retained because of the small sample size of some populations. Deviations from Hardy-Weinberg equilibrium were tested using the exact probability test of Guo \& Thompson (1992) available in GENEPOP 3.2a (Raymond \& Rousset, 1995). Significance levels were calculated at each locus for each population and over all loci for each popula- 
tion. Genotypic linkage disequilibrium between each pair of loci was estimated by Fisher's exact tests with GENEPOP 3.2a software. Both tests for deviations from Hardy-Weinberg equilibrium and for linkage disequilibrium used a Markov chain (1000 dememorisation steps, 100 batches, 1000 iterations/ batch).

The PHYLIP package (Felsenstein, 1993) was used to calculate Cavalli-Sforza \& Edwards (1967) chord distances between populations and to perform a neighbour-joining (NJ) cluster analysis. Statistical support for the branching pattern was obtained with 2000 bootstrap procedures. Significant difference in allelic frequencies was determined by testing the null hypothesis of homogeneity in allelic distribution between the clusters identified in the NJ tree using a Fisher's exact test. This test was performed with GENEPOP 3.2a using the Markov chain method (1000 dememorisation steps, 100 batches, 1000 iterations/ batch). In order to test if stepwise-like mutations at microsatellite loci contributed significantly to the genetic differentiation between clusters, we implemented a test based on a randomisation procedure of allele sizes proposed by Hardy et al. (2003) using the software SPAGeDI 1.1 (Hardy \& Vekemans, 2002). A significant difference indicates that allele-size based statistics $\left(R_{\mathrm{ST}}\right)$ perform better than identity-based ones $\left(F_{\mathrm{ST}}\right)$. This test can also provide valuable insights into the main causes of population differentiation (i.e. mutation versus drift) by comparing $F_{\mathrm{ST}}$ and $R_{\mathrm{ST}}$ values. $F_{\mathrm{ST}}$ and $R_{\mathrm{ST}}$ are expected to be of the same magnitude when differentiation is only caused by drift, whereas $R_{\mathrm{ST}}$ is expected to be larger than $F_{\mathrm{ST}}$ under the contribution of stepwise-like mutations (see Lugon-Moulin et al., 1999; Hardy et al., 2003). We also performed this test between populations within clusters to determine the proper statistic for assessing their genetic differentiation. Significance was estimated using 1000 randomisation procedures. Based on the results of these tests, genetic differentiation between populations was estimated using pairwise $F_{\mathrm{ST}}$ estimates according to Weir \& Cockerham (1984) and pair-wise $\rho_{\text {ST }}$ estimates, an unbiased estimator of Slatkin's $R_{\mathrm{ST}}$, according to Michalakis \& Excoffier (1996). Pair-wise $F_{\mathrm{ST}}$ and $\rho_{\mathrm{ST}}$ values were calculated using ARLEQUIN 2.0 software (Schneider, Roessli \& Excoffier, 2000). Significance was estimated using 10000 permutations. For each cluster, a hierarchical analysis of molecular variance (AMOVA, Excoffier,
Smouse \& Quattro, 1992) was used to assess the partitioning of microsatellite variation in allelic frequencies $\left(F_{\mathrm{ST}}\right)$ among populations between and within river basins. AMOVA calculations were performed using ARLEQUIN 2.0 software and the significance of the variance components was tested using 10000 permutations. We also investigated the possibility of secondary contacts between $A$. pallipes lineages because the $\mathrm{NJ}$ analysis revealed the presence of different lineages in the same river drainage. Because of the limited number of microsatellite markers available and because of their relatively low polymorphism, we used correspondence analysis (CA) rather than other methods that are more computationally intensive and that require more markers. CA was performed on the matrix of allele counts per sample at the population and the individual levels using GENETIX 4.05 software. This qualitative approach is useful for analysing the homogeneity of a given sample, and it was proven very efficient in the study of hybrid zones and in the identification of admixed populations (Daguin, Bonhomme \& Borsa, 2001; Aurelle, Cattaneo-Berrebi \& Berrebi, 2002; Bierne et al., 2003).

When applicable, the significance of the $P$-values was adjusted using the Bonferroni sequential correction for multiple statistical tests (Rice, 1989), with an initial $\alpha$-value of $0.05 / k$ ( $k$ being the number of comparisons).

\section{Results}

The microsatellite markers showed a relatively low level of within population polymorphism, but exhibited important variations between populations. Allelic frequencies in the 44 populations of $A$. pallipes are reported in the Appendix. The number of alleles per locus ranged from 2 for the locus Ap6 to 15 for the locus Ap7 (Table 2). The mean allelic diversity per locus varied between 1.0 in the population of Laurio to 3.0 in the populations of Artix and Saint Romain, with an average of 1.9 over all populations (Table 1). The proportion of expected heterozygous individuals per population ranged between 0.000 and 0.564 (Table 1). The mean expected heterozygosity in the French populations of $A$. pallipes was 0.235. After sequential Bonferroni correction for multiple tests, no significant departure from Hardy-Weinberg equilibrium was observed in each population, both at each 
Table 2 Total number of alleles per locus $(A)$, observed $\left(H_{\mathrm{O}}\right)$ and expected $\left(H_{\mathrm{E}}\right)$ heterozygosity, deviation from Hardy-Weinberg equilibrium $\left(F_{\mathrm{IS}}\right)$ for each locus in each population

\begin{tabular}{|c|c|c|c|c|c|c|c|c|c|c|c|c|c|c|c|c|c|c|c|c|}
\hline \multirow[b]{3}{*}{ Locus } & \multicolumn{4}{|c|}{$A p 2$} & \multicolumn{4}{|c|}{ Ap3 } & \multicolumn{4}{|c|}{ Ap5 } & \multicolumn{4}{|c|}{ Ap6 } & \multicolumn{4}{|c|}{$A p 7$} \\
\hline & \multicolumn{4}{|l|}{4} & \multicolumn{4}{|l|}{4} & \multicolumn{4}{|l|}{8} & \multicolumn{4}{|l|}{2} & \multicolumn{4}{|l|}{15} \\
\hline & $A$ & $F_{\mathrm{IS}}$ & $H_{\mathrm{O}}$ & $H_{\mathrm{E}}$ & $A$ & $F_{\mathrm{IS}}$ & $H_{\mathrm{O}}$ & $H_{\mathrm{E}}$ & $A$ & $F_{\mathrm{IS}}$ & $H_{\mathrm{O}}$ & $H_{\mathrm{E}}$ & $A$ & $F_{\mathrm{IS}}$ & $H_{\mathrm{O}}$ & $H_{\mathrm{E}}$ & $A$ & $F_{\mathrm{IS}}$ & $H_{\mathrm{O}}$ & $H_{\mathrm{E}}$ \\
\hline GAR-1 & 1 & - & - & - & 1 & - & - & - & 3 & +0.05 & & & 2 & -0.17 & 0.50 & & 3 & & 0.26 & \\
\hline GAR-2 & 3 & -0.11 & 0.66 & 0.60 & 2 & +0.20 & 0.42 & 0.52 & 4 & +0.01 & 0.67 & 0.67 & 2 & -0.16 & 0.33 & 0.29 & 4 & -0.14 & 0.83 & 0.73 \\
\hline AR-3 & 1 & - & - & - & 2 & - & 0.09 & 0.09 & 2 & -0.06 & 0.20 & 0.19 & 1 & - & - & - & 1 & - & - & - \\
\hline GAR-4 & 1 & - & - & - & 2 & +0.02 & 0.35 & 0.36 & 2 & & 0.25 & 0.22 & 1 & - & - & . & 1 & - & - & - \\
\hline GAR-5 & 1 & - & - & - & 1 & - & - & - & 2 & +0.23 & 0.33 & 0.42 & 1 & - & - & - & 3 & +0.31 & 0.40 & 0.57 \\
\hline AR-6 & 2 & -0.23 & 0.64 & 0.52 & 1 & - & - & - & 3 & +0.04 & 0.54 & 0.57 & 2 & -0.13 & 0.54 & 0.48 & 2 & - & 0.10 & 0.10 \\
\hline GAR-7 & 1 & - & - & - & 1 & - & - & - & 2 & - & 0.05 & 0.0 & 1 & - & - & - & 1 & - & - & - \\
\hline GAR-8 & 1 & - & - & - & 2 & - & 0.05 & 0.05 & 1 & - & - & - & 1 & - & - & - & 2 & +0.49 & 0.16 & 0.32 \\
\hline GAR-9 & 3 & +0.21 & 0.43 & 0.54 & 3 & +0.20 & 0.36 & 0.44 & 2 & -0.20 & 0.38 & 0.32 & 2 & +0.30 & 0.21 & 0.30 & 4 & +0.09 & 0.61 & 0.73 \\
\hline GAR-10 & 2 & - & 0.20 & 0.20 & 2 & - & 0.20 & 0.20 & 2 & & 0.40 & 0.3 & 2 & - & 0.20 & & 5 & & & 0.78 \\
\hline ADO-11 & 3 & +0.06 & & 0.56 & 2 & +0.39 & & & 2 & -0.06 & & & 2 & +0.08 & & & 4 & & 74 & \\
\hline ADO-12 & 3 & +0.18 & 0.39 & 0.47 & 2 & -0.13 & 0.28 & 0.2 & 3 & +0.05 & 0.44 & 0.46 & 2 & - & 0.05 & 0.05 & 2 & -0.13 & 0.28 & 0.2 \\
\hline AUD-13 & 1 & - & - & - & 1 & - & - & - & 1 & - & - & - & 1 & - & - & - & 1 & - & - & - \\
\hline AUD-14 & 1 & - & - & - & 1 & - & - & - & 2 & - & & & 1 & - & - & - & & - & - & - \\
\hline HER-15 & 1 & - & - & - & 2 & - & 0.14 & 0.14 & 1 & - & - & - & 1 & - & - & - & 2 & - & 0.14 & 0.1 \\
\hline HER-16 & 1 & - & - & - & 1 & - & - & - & 2 & -0.03 & 0.12 & 0.11 & 1 & - & - & - & 1 & - & - & - \\
\hline ORN-17 & 1 & - & - & - & 1 & - & - & - & 1 & - & - & - & 1 & - & - & - & 2 & +0.31 & 0.36 & 0.5 \\
\hline CHA- 18 & 2 & - & 0.09 & 0.09 & 1 & - & - & - & 2 & +0.13 & 0.36 & 0.41 & 2 & -0.05 & 0.54 & 0.52 & 1 & - & - & - \\
\hline SEV-19 & 2 & -0.03 & 0.10 & 0.10 & 2 & -0.06 & 0.16 & 0.15 & 2 & -0.02 & 0.47 & 0.46 & 2 & +0.53 & 0.42 & 0.4 & 2 & -0.12 & 0.26 & 0.2 \\
\hline SEV-20 & 2 & +0.16 & .42 & 0.50 & 2 & - & 0.04 & 0.04 & 2 & +0.01 & 0.42 & 0.42 & 2 & & 0.50 & & 1 & - & - & - \\
\hline SEV-21 & 2 & -0.19 & 0.35 & 0.30 & 2 & -0.06 & 0.15 & 0.14 & 4 & +0.15 & 0.53 & 0.61 & 2 & +0.24 & 0.20 & 0.26 & 3 & -0.04 & 0.44 & 0.4 \\
\hline LOI-22 & 2 & -0.12 & 0.57 & 0.51 & 1 & - & - & - & 4 & +0.20 & 0.41 & 0.51 & 2 & +0.30 & 0.33 & 0.47 & 3 & -0.15 & 0.33 & 0.2 \\
\hline LOI-23 & 2 & +0.18 & 0.36 & 0.44 & 3 & -0.04 & 0.64 & 0.61 & 2 & & 0.43 & & 1 & - & - & - & 2 & -0.05 & 0.14 & 0.1 \\
\hline LOI-24 & 2 & -0.29 & 0.47 & 0.37 & 1 & - & - & - & 3 & +0.07 & 0.37 & 0.40 & 2 & -0.22 & 0.56 & 0.46 & 1 & - & - & - \\
\hline LOI-25 & 1 & - & - & - & 1 & - & - & - & 2 & -0.33 & 0.67 & 0.53 & 2 & -0.09 & 0.28 & 0.26 & 1 & - & - & - \\
\hline LOI-26 & 1 & - & - & - & 2 & -0.29 & 0.50 & 0.39 & 2 & -0.12 & 0.30 & & 1 & - & - & - & 2 & - & 0.11 & 0.11 \\
\hline LOI-27 & 1 & - & - & - & 2 & +0.3 & & & 2 & & & & 1 & - & - & - & 2 & -0.03 & 0. & 0. \\
\hline LOI-28 & 1 & - & - & - & 2 & - & 0.07 & 0.07 & 2 & +0.30 & 0.21 & 0.30 & 1 & - & - & - & 3 & +0.21 & 0.50 & 0.6 \\
\hline LOI-29 & 1 & - & - & - & 2 & -0.08 & 0.21 & 0.20 & 2 & +0.25 & 0.36 & & 1 & - & - & - & 4 & +0.21 & 0.5 & 0.6 \\
\hline LOI-30 & 1 & - & - & - & 2 & -0.10 & 0.55 & 0.5 & 2 & & 0.25 & 0.30 & 1 & - & - & - & 2 & - & 0.05 & 0.0 \\
\hline RHI-31 & 2 & -0.23 & 0.44 & 0.37 & 1 & - & - & - & 2 & +0.19 & 0.37 & 0.46 & 2 & -0.07 & 0.22 & 0.21 & 1 & - & - & - \\
\hline RHI-32 & 2 & -0.38 & 0.60 & 0.44 & 1 & - & - & - & 2 & +0.22 & 0.40 & 0.50 & 2 & +0.04 & 0.50 & 0.52 & 2 & -0.06 & 0.20 & 0.1 \\
\hline RHO-33 & 2 & -0.22 & 0.56 & 0.47 & 3 & +0.24 & 0.37 & 0.49 & 3 & & 0.50 & 0.64 & 2 & & 0.56 & & 1 & - & - & - \\
\hline RHO-34 & 3 & -0.27 & 0.83 & 0.66 & 1 & - & - & - & 2 & +0.20 & 0.42 & 0.52 & 2 & -0.10 & 0.25 & 0.23 & 2 & - & 0.08 & 0.0 \\
\hline RHO-35 & 2 & +0.33 & 0.21 & 0.31 & 1 & - & - & - & 3 & +0.19 & 0.46 & 0.56 & 2 & -0.29 & 0.62 & 0.49 & 1 & - & - & - \\
\hline RHO-36 & 1 & - & - & - & 2 & +0.65 & 0.06 & 0.17 & 4 & & 0.50 & 0.59 & 2 & -0.11 & 0.25 & 0.22 & 5 & +0.32 & 0.50 & 0.7 \\
\hline RHO-37 & 1 & - & - & - & 2 & -0.12 & 0.30 & 0.27 & 2 & +0.10 & 0.40 & & 1 & - & - & - & 3 & -0.03 & & 0.19 \\
\hline RHO-38 & 1 & - & - & - & 2 & -0.04 & 0.13 & 0.13 & 3 & -0.07 & 0.27 & 0.25 & 1 & - & - & - & 4 & +0.24 & 0.53 & 0.70 \\
\hline RHO-39 & 1 & - & - & - & 3 & -0.04 & 0.17 & 0.16 & 2 & -0.03 & 0.50 & 0.48 & 1 & - & - & - & 6 & -0.04 & 0.83 & 0.80 \\
\hline RHO-40 & 1 & - & - & - & 2 & -0.15 & 0.30 & 0.26 & 2 & +0.30 & 0.26 & 0.37 & 1 & - & - & - & 2 & +0.15 & 0.35 & 0.4 \\
\hline RHO-41 & 1 & - & - & - & 2 & -0.04 & 0.40 & 0.38 & 3 & +0.22 & 0.35 & 0.45 & 1 & - & - & - & 3 & -0.03 & 0.60 & 0.58 \\
\hline RHO-42 & 1 & - & - & - & 2 & +0.63 & 0.12 & 0.32 & 2 & +0.22 & 0.43 & 0.54 & 1 & - & - & - & 1 & - & - & - \\
\hline SEI-43 & 2 & -0.12 & 0.47 & 0.42 & 2 & -0.03 & 0.10 & 0.10 & 2 & +0.08 & 0.31 & 0.34 & 2 & -0.06 & 0.16 & 0.15 & 2 & -0.03 & 0.11 & 0.1 \\
\hline SEI-44 & 2 & +0.25 & 0.40 & 0.53 & 2 & +0.56 & 0.20 & 0.44 & 2 & +0.39 & 0.30 & 0.48 & 1 & - & - & - & 1 & - & - & - \\
\hline
\end{tabular}

Significant departures from Hardy-Weinberg equilibrium prior to the sequential Bonferroni corrections are reported in bold.

locus (Table 2) and over all loci (Table 1). It is also important to note that despite the scoring difficulties mentioned previously, no deviation from HardyWeinberg equilibrium was observed at locus Ap5 over all populations, suggesting that genotypes were correctly scored for most or all individuals. No significant linkage disequilibrium was revealed between any of the locus pairs (data not shown). 
The NJ dendrogram based on the Cavalli-Sforza \& Edwards (1967) chord distance revealed that the genetic differentiation between populations was gradual from south to north, but with two genetically differentiated groups corresponding to northern (group I) and southern (group II) French populations (Fig. 2). These two entities displayed significant differences in allele frequencies at the five microsatellite loci $(P<0.001)$. Allele frequencies for each group of populations are shown in Fig. 3. The test based on allele sizes permutations revealed that stepwise-like mutations contributed significantly to the genetic differentiation between northern French and southern French populations $(P=0.028)$, indicating that $R$-statistics would be more suitable than $F$-statistics to assess genetic differentiation between these line-

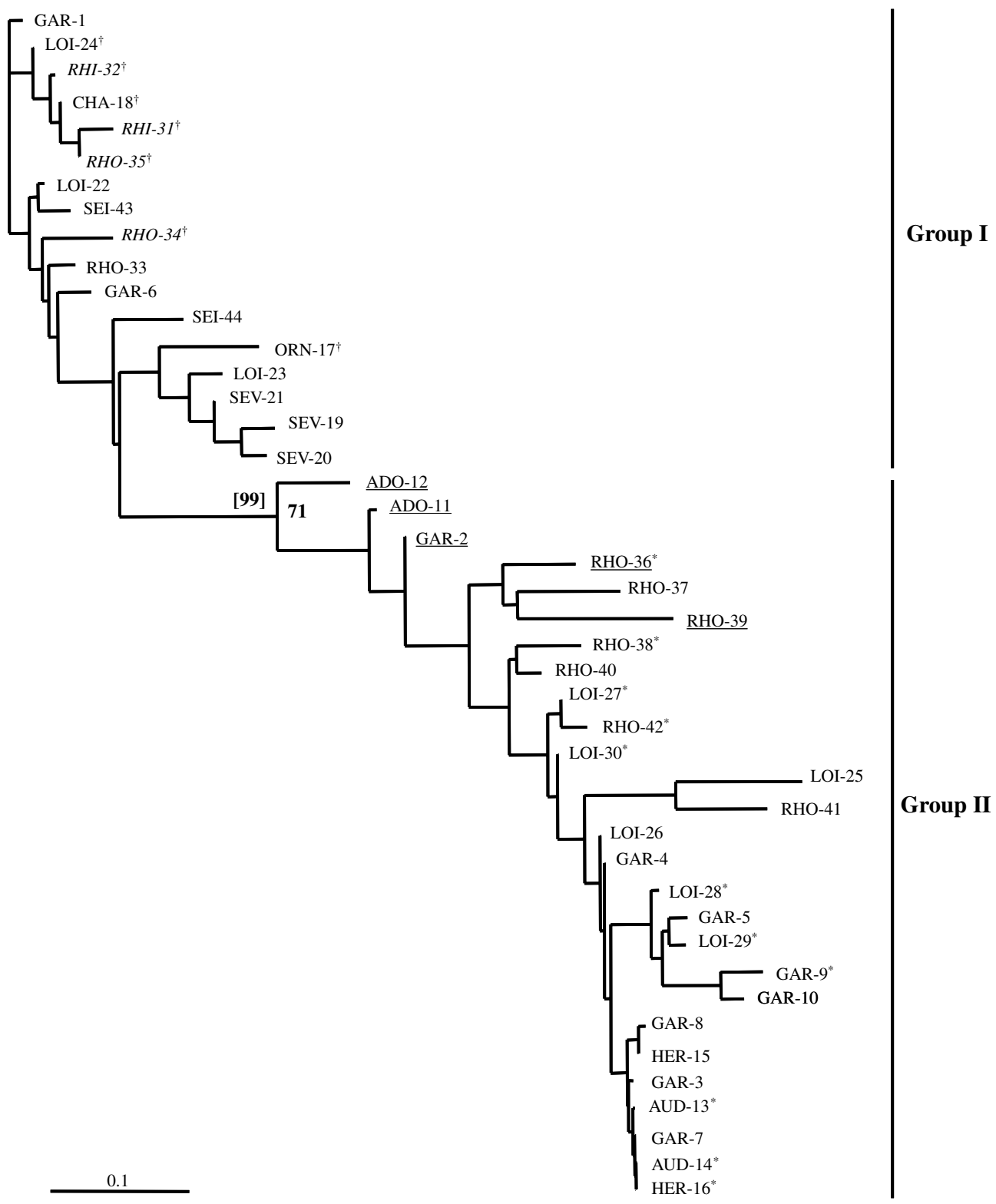

Fig. 2 Neighbour-joining dendrogram based on Cavalli-Sforza \& Edwards (1967) chord distances between French populations. Bootstrap values (2000 replicates) are shown if $>55 \%$. The value reported in square brackets corresponds to the bootstrap value obtained after removing the five admixed populations (underlined). We have indicated the populations previously assigned to a northern $(\dagger)$ or a southern $(*)$ French lineage by Grandjean \& Souty-Grosset (2000) and Gouin et al. (2001). Populations in italics correspond to the north-eastern lineage proposed by Gouin et al. (2001). 

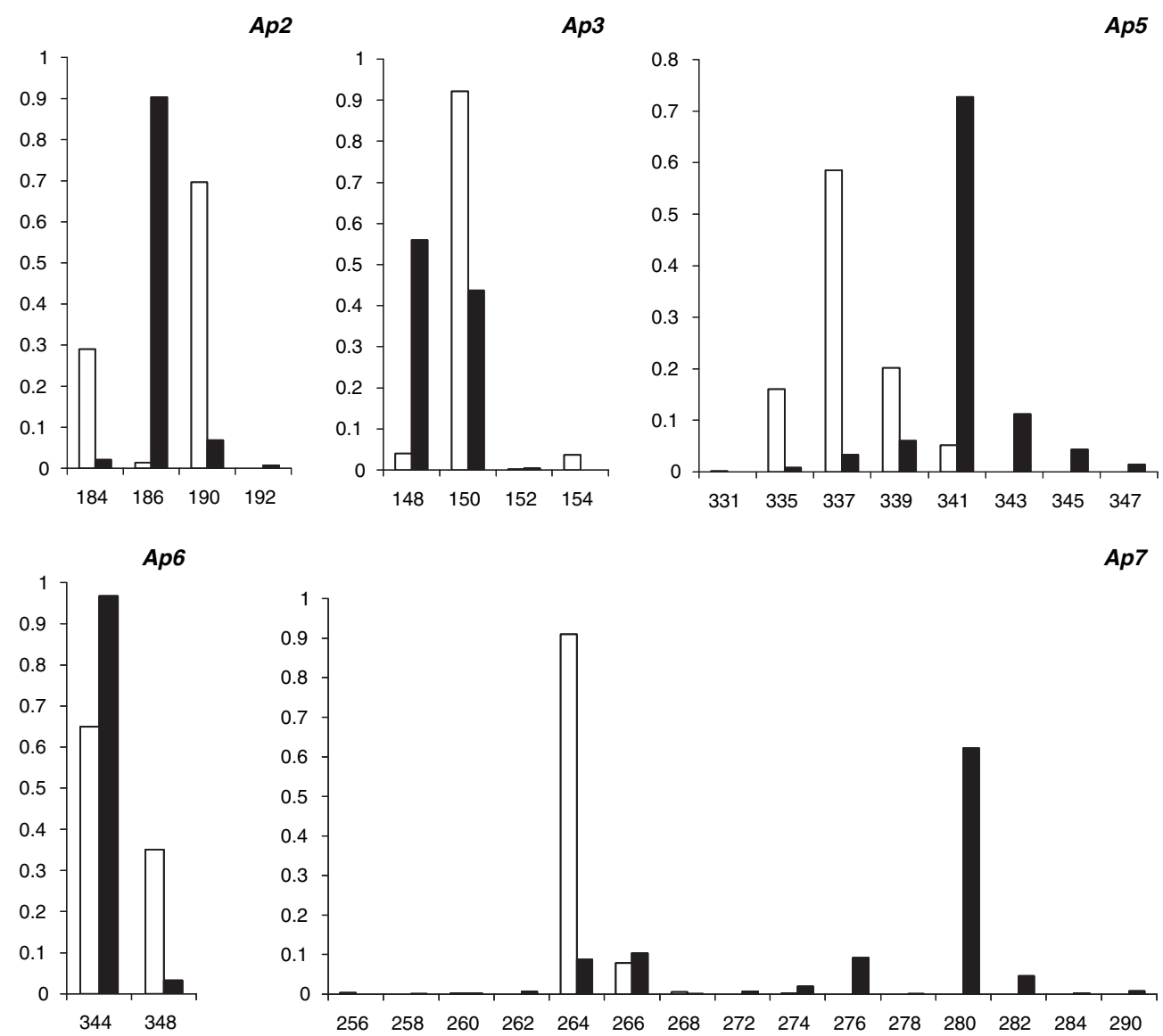

Fig. 3 Distribution of allele frequencies in the two lineages of A. pallipes for each microsatellite locus (group I in white; group II in black).

ages. No significant effect of stepwise-like mutations was detected between populations within each of the groups $(P>0.05)$, illustrating that genetic drift was the main force responsible for the genetic differentiation observed between populations within groups and that $F$-statistics would be more appropriate for measuring population structure within each lineage.

Pair-wise $F_{\mathrm{ST}}$ and $\rho_{\mathrm{ST}}$ revealed that most of the French A. pallipes populations were highly genetically differentiated, except north-eastern populations (RHI$31 / 32$, RHO-33/34/35) and a group of southern populations (GAR-3/4/7/8, AUD-13/14, HER-15/ 16; Table 3). A few populations with very low sample size (GAR-10, LOI-25, RHI-32, RHO-42) displayed high $F_{\mathrm{ST}}$ values that were not significant, and will require additional samples. As described in Table 4, genetic differentiation appeared more pronounced between populations sampled in southern France $\left(F_{\mathrm{ST}}=0.461 ; P<0.001\right)$ compared with populations sampled in northern France $\left(F_{\mathrm{ST}}=0.226 ; P<0.001\right)$. AMOVA also revealed that northern and southern French populations of $A$. pallipes were significantly differentiated between the different major drainages (group I: $F_{\mathrm{CT}}=0.08 ; P=0.007$; group II: $F_{\mathrm{CT}}=0.265$; $P<0.001$ ). About $15 \%$ of the total genetic variance was attributable to differentiation between populations within river basins in northern populations and about $20 \%$ in southern populations, indicating that they were genetically structured. However, it must be noted that there was more variation within river basins than between river basins in northern populations and almost as much variation within as between basins in southern populations.

The CA performed on A. pallipes populations clearly separated populations from NJ group I and II along the first axis, with an inertia of $36.6 \%$ (Fig. 4). However, a group of five southern populations from NJ group II, Saint Romain (GAR-2), Louet (ADO-11), 


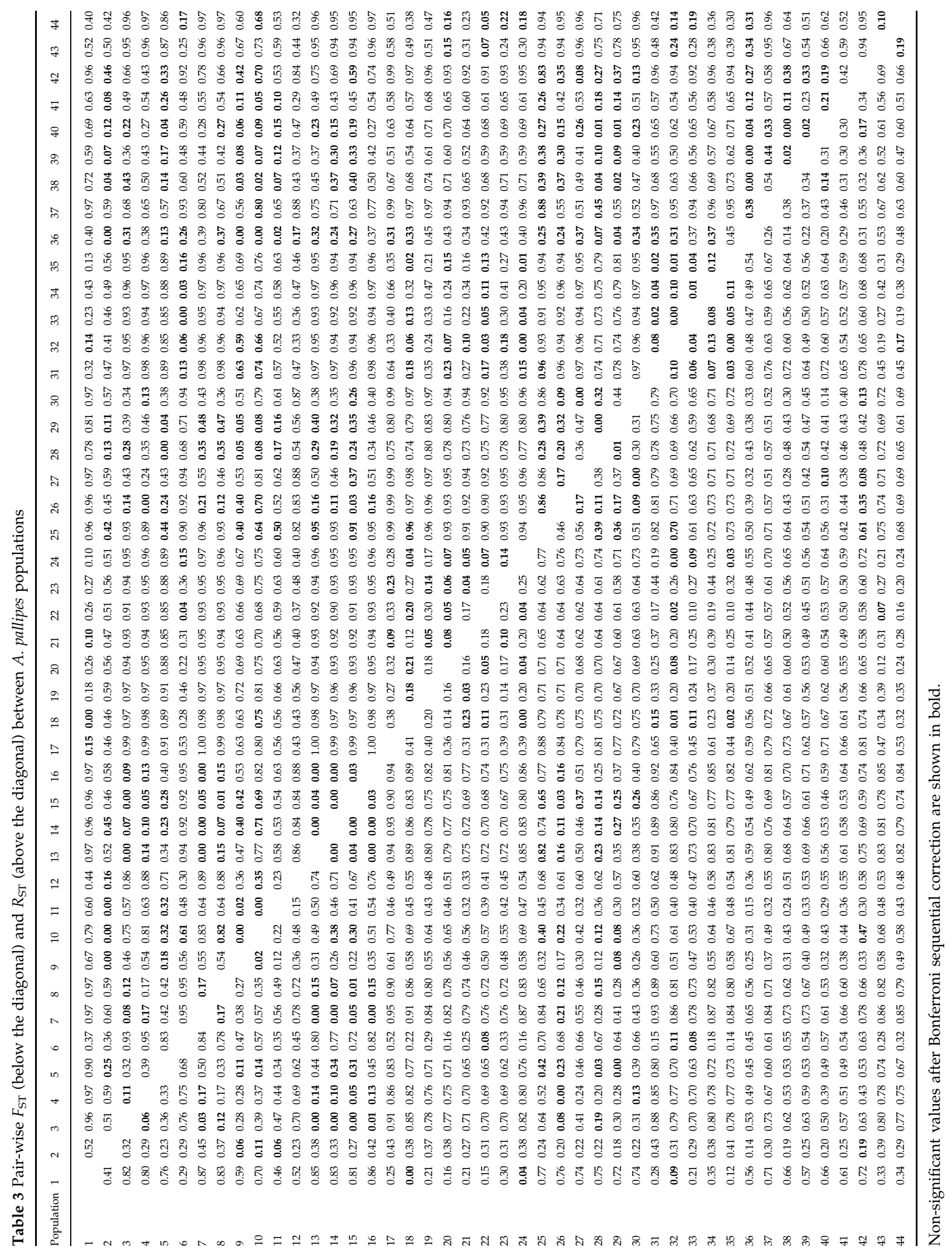




\begin{tabular}{|c|c|c|c|c|}
\hline Variance components & d.f. & $\begin{array}{l}\% \text { Total } \\
\text { variance }\end{array}$ & F-statistics & $P$-value \\
\hline \multicolumn{5}{|l|}{ Northern French populations (group I) } \\
\hline Among river basins & 7 & 8.22 & $F_{\mathrm{CT}}=0.082$ & 0.007 \\
\hline Among populations within river basins & 9 & 14.38 & $F_{\mathrm{SC}}=0.157$ & $<0.001$ \\
\hline Within populations & 559 & 77.40 & $F_{\mathrm{ST}}=0.226$ & $<0.001$ \\
\hline \multicolumn{5}{|l|}{ Southern French populations (group II) } \\
\hline Among river basins & 5 & 26.52 & $F_{\mathrm{CT}}=0.265$ & $<0.001$ \\
\hline Among populations within river basins & 21 & 19.63 & $F_{\mathrm{SC}}=0.267$ & $<0.001$ \\
\hline Within populations & 747 & 53.85 & $F_{\mathrm{ST}}=0.461$ & $<0.001$ \\
\hline
\end{tabular}

Table 4 Hierarchical partitioning of genetic variance (AMOVA) at microsatellite loci among populations between and within river basins in northern and southern French populations
Lys (ADO-12), Sélignac (RHO-36) and Mezayon (RHO-39), appeared in fact to have an intermediate genetic composition between populations of the two lineages. It is important to note that the bootstrap value between the two NJ groups reaches $99 \%$ when these five populations are removed from the analysis (Fig. 2). The CA implemented on the individual genotypes confirmed the heterogeneous composition of the populations described above, with individuals distributed between the two groups (Fig. 5). One sample from the population of Saint Romain (GAR-2) was clearly plotted among individuals from NJ group I along the first CA axis. Populations of Louet (ADO11) and Lys (ADO-12) also showed specimens with a genetic composition close to that of individuals from $\mathrm{NJ}$ group I. Most of the individuals from Lys were distributed between the two groups.

\section{Discussion}

The primary objective of this study was to quantify the extent of microsatellite variation in the French populations of A. pallipes. Our results revealed only a moderate level of polymorphism despite an exhaustive sampling regime. This finding is not surprising as freshwater crayfish are known to display a low genetic variability (Fetzner \& Crandall, 2001). However, with an average level of heterozygosity of 0.235 , the polymorphism revealed with the microsatellites was much higher than the polymorphism previously recorded from allozymes and RAPDs (Attard \& Vianet, 1985; Gouin et al., 2001). This variation was sufficient to provide a clear picture of the genetic differentiation among French populations, between and even within river basins.

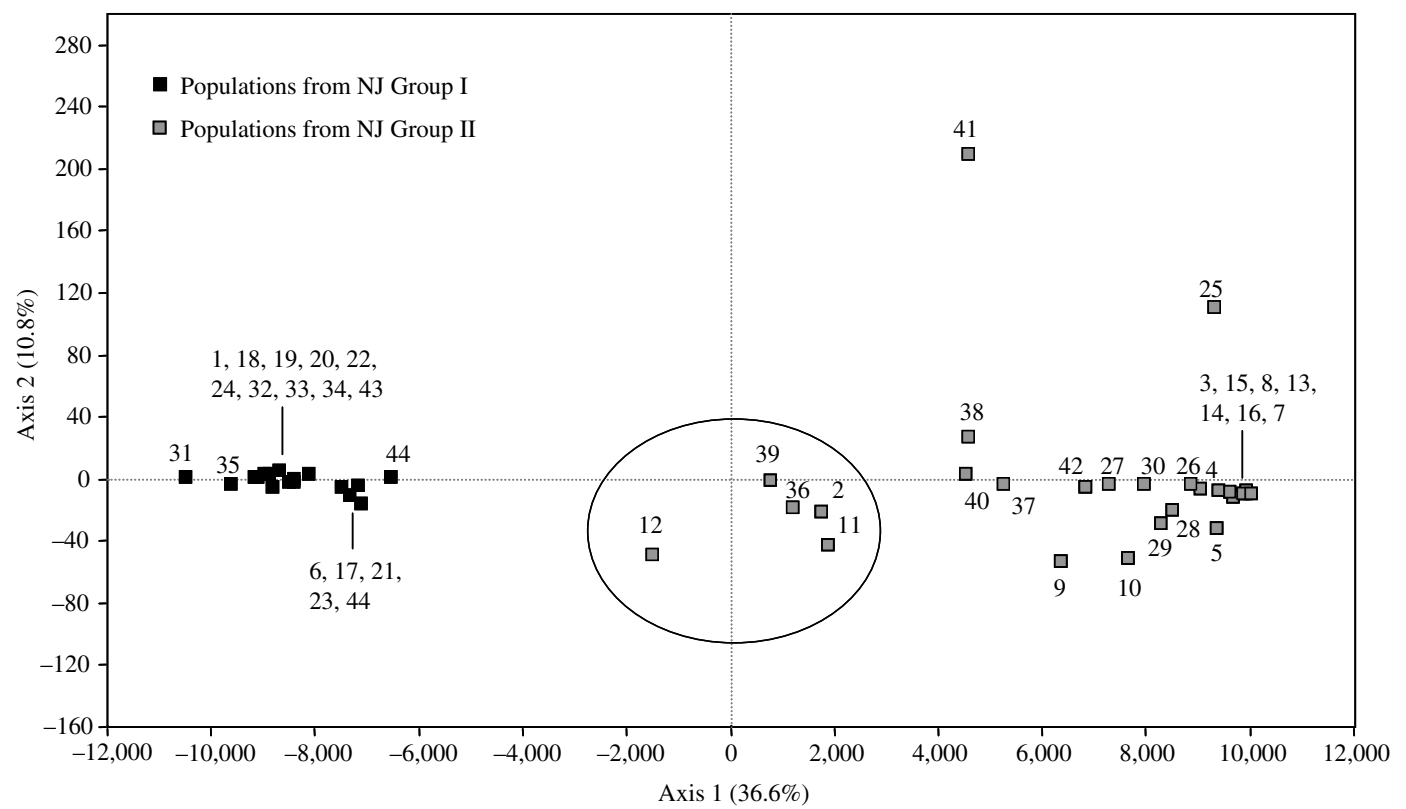

Fig. 4 Correspondence analysis: projection of A. pallipes populations on the first two axes. Populations of Saint Romain (GAR-2), Louet (ADO-11), Lys (ADO-12), Sélignac (RHO-36) and Mezayon (RHO-39), with an intermediate genetic composition, are circled. 


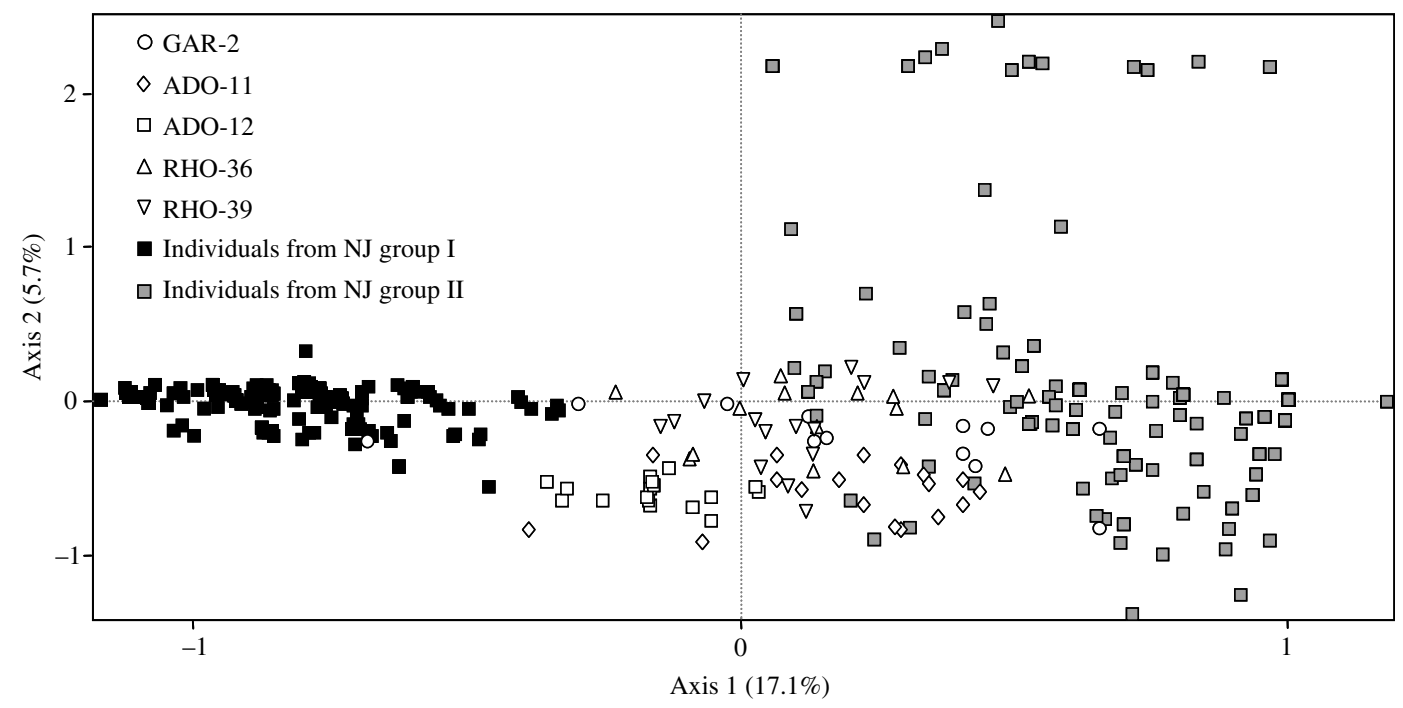

Fig. 5 Correspondence analysis: projection of the individual genotypes on the first two axes. GAR-2 = Saint Romain, ADO-11 = Louet, ADO-12 = Lys, RHO-36 = Sélignac, RHO-39 = Mezayon.

\section{Possible refugial areas for A. pallipes}

Based on the analysis of mtDNA by RFLP, Grandjean \& Souty-Grosset (2000) showed the existence of two genetically differentiated entities of $A$. pallipes in France corresponding to northern and southern populations. The same dichotomy was revealed in the present study using microsatellite markers (see Fig. 2), with stepwise-like mutations contributing significantly to the genetic differentiation between these two groups. Recent studies have demonstrated that microsatellite markers can be effective for discerning historical relationships of divergent populations (Angers \& Bernatchez, 1998; Goodman, 1998; Koskinen et al., 2002; Hardy et al., 2003; Fraser \& Bernatchez, 2005). According to Estoup \& Angers (1998), complete genetic isolation for 2000 generations would constitute a critical value below which the mutation process for microsatellite markers would have a limited influence on population structuring. As A. pallipes has a generation time of approximately 4 years, our results suggest that the separation between northern and southern populations exceeded 8000 years, which would place it near the last glaciation period of the Pleistocene. This assumption is further supported by the $1.25 \%$ average haplotype divergence found between northern and southern populations by Grandjean \& Souty-Grosset (2000), which is consistent with divergence beginning in the
Pleistocene (Avise, 1998). Therefore, the congruence between results obtained from these different molecular markers clearly confirms the north/south subdivision of A. pallipes French populations. According to the present distribution of $A$. pallipes, the hypothesis of two refuges during the last glacial, one on the Atlantic coast and one on the Mediterranean coast, from which the post-Pleistocene dispersal would have occurred seems very likely and is in agreement with hypotheses already proposed for freshwater species distributed in western Europe (Nagel, 2000; Bernatchez, 2001). In brown trout Salmo trutta (Linnaeus 1758), the best-studied freshwater species in Europe, two lineages have also been described in France: a Mediterranean lineage which is distributed in river drainages along the Mediterranean coast and in the main Rhône river drainage and an Atlantic lineage distributed in the Garonne, the Loire, the Seine, the Rhine and the upper Rhône river systems (GarciaMarin, Utter \& Pla, 1999; Bernatchez, 2001; Antunes et al., 2002). As these two species (S. trutta and A. pallipes) share the same habitat, we can postulate that they probably shared these two refugial areas during the Pleistocene. However, given that Spain harbours only populations of the species A. italicus (Grandjean et al., 2000, 2001), this eliminates the possibility of a northern expansion of $A$. pallipes from a refuge in Atlantic drainages of Iberia (Garcia-Marin et al., 1999). According to Aurelle et al. (2002), south- 
western France was ice-free during the last glacial events and this area could have been a possible glacial refuge for brown trout. It is therefore very likely that the Atlantic refuge for A. pallipes was located in the Adour and the Garonne rivers as well. Lastly, our results clearly reject the hypothesis of a third refuge for A. pallipes in the Rhine river system suggested by Gouin et al. (2001) from analysis of RAPD marker data. As revealed in the present study, north-eastern populations are not genetically differentiated, and the pattern observed by Gouin et al. (2001) could have been an artefact because of the limited number of populations sampled in northern France.

\section{Secondary contacts between A. pallipes lineages}

There is some evidence from our data that genetic introgression between the Atlantic and the Mediterranean lineages might have occurred in five populations belonging to the Garonne, the Adour and the lower Rhône river basins. The strongest evidence was found in the population of Saint Romain (GAR-2) where the CA unambiguously revealed the presence of individuals from each lineage associated with individuals with intermediate genotypes. None of these populations displayed significant Hardy-Weinberg or linkage disequilibria, which indicates that genetic introgression was probably not very recent (Poteaux, Bonhomme \& Berrebi, 1999; Beaumont et al., 2001). Indeed, population disequilibria should be negligible after a few generations of random mating (Barton, 2000). The fact that these populations reached equilibrium also indicates that there was no apparent reproductive isolation and genetic barrier to gene flow between crayfish from these two lineages (Barton \& Hewitt, 1985; Barton \& Gale, 1993).

Whether past secondary contacts between the Atlantic and the Mediterranean lineages were natural or artificial is difficult to answer. However, compared with the brown trout model, the presence of crayfish from the Mediterranean lineage in the Garonne and the upper Loire river systems, suggesting the colonisation of south-western France from a Mediterranean refuge, is surprising. In fish, and especially in trout, natural secondary contacts did not occur between Mediterranean and Atlantic lineages in southern France (Bernatchez, 2001; Aurelle et al., 2002). Even if $A$. pallipes has the ability to walk, which could have allowed this species to cross obstacles that fishes could not and thereby colonise south-western France, this species would have still used pathways having at least shallow waters; shallow waters that a fish like the brown trout could have easily employed. Moreover, no major difference in habitat requirements has been revealed between populations throughout its distribution area (Neveu, 2000; Grandjean, Momon \& Bramard, 2003; Trouilhé et al., 2003) and the French climate varies gradually from north to south with no drastic change that could explain such a distribution through ecological replacement. In fact, a rational hypothesis is that crayfish from the Mediterranean stock could have been introduced in the upper part of the Garonne and the Loire river systems. Humanmediated translocation of white-clawed crayfish appears indeed to have been a common practice throughout western Europe (Souty-Grosset et al., 1997; Largiadèr et al., 2000; Grandjean et al., 2001; Gouin et al., 2003; Fratini et al., 2005; Trontelj, Machino \& Sket, 2005) and particularly in France (Machino et al., 2004). It is therefore plausible that crayfish could have been translocated from east to west, leading to the establishment of new populations or to genetic admixture between Atlantic and Mediterranean stocks. The translocation of specimens from a Mediterranean lineage would not be specific to $A$. pallipes since it has also been reported locally in brown trout as a result of stocking events and in freshwater mussels (Berrebi et al., 2000; Nagel, 2000).

\section{Population genetic structure between and within rivers}

Hydrography has a strong impact on the genetic structure of most species colonising continental freshwaters (Ward, Woodwark \& Skibinski, 1994; Hébert et al., 2000; Costello et al., 2003). While previous studies failed to detect any influence of hydrography on the distribution of the genetic variation in A. pallipes (Grandjean \& Souty-Grosset, 2000; Gouin et al., 2001), the microsatellite markers used here revealed that river systems had in fact a significant impact on population differentiation. Although we suspect artificial secondary contacts between crayfishes from the Atlantic and the Mediterranean refuges in southwestern France, the high degree of genetic differentiation observed between river basins in southern populations indicates that southern populations were probably highly structured prior to these events. The fact that the differentiation between populations of a 
river basin was as high as or higher than differentiation between river basins could be explained by two, not necessarily exclusive, hypotheses: (i) the translocation of crayfish from different river basins, as revealed between the two lineages in the present study and (ii) a common origin of populations of different river basins followed by little gene flow within basins.

The high degree of genetic differentiation within river basins revealed by microsatellite analysis strongly suggests the absence of significant gene flow between populations and confirms the previous observations made from mtDNA and RAPD markers (Grandjean et al., 1997; Grandjean \& Souty-Grosset, 2000; Gouin et al., 2001). Habitat fragmentation because of the degradation of water quality has progressively confined $A$. pallipes populations to headwater river systems (Changeux, 2003). These populations are now isolated and thus increasingly subject to the effects of random genetic drift including rapid loss of genetic variability (Hartl \& Clark, 1997; Amos \& Harwood, 1998). Therefore, the various levels of heterozygosity observed in the French populations could be due to differences in local population sizes. The proportional relationship between intra-population genetic variability and population size has been observed in numerous species (Frankham, 1996) and was proposed by Gouin et al. (2001) to explain the variation in intra-population diversity in A. pallipes revealed with RAPD markers.

However, two additional factors capable of exacerbating the impact of genetic drift in $A$. pallipes populations through bottleneck events have to be considered: demographic fluctuations and humanmediated translocations of crayfish. Concerning the first factor, variation in population size because of demographic and environmental stochasticity reduces effective population size and accentuates the loss of genetic variability (Sherwin \& Moritz, 2000; Frankham, Ballou \& Briscoe, 2002). In the white-clawed crayfish, populations can experience drastic reductions in size during severe droughts and periodic chemical pollution events (pesticides, fertilisers). For example, La Rune (Vienne, France) was polluted in 1999 with a chlorinated hydrocarbon pesticide, which killed an estimated 4520 A. pallipes, virtually the entire population. The following year ten crayfish that had escaped the pollution were discovered in a small affluent, from which the main brook is being recolonised. There is no doubt that bottlenecks of this magnitude can have a strong impact on the genetic diversity of $A$. pallipes populations. Uncontrolled translocations of crayfish can also have a significant impact on the genetic differentiation of white-clawed crayfish populations (Lörtscher et al., 1997; Santucci et al., 1997; Grandjean et al., 2001; Gouin et al., 2003; Fratini et al., 2005). In a study of Irish populations, Gouin et al. (2003) showed that a succession of founder effects because of step-by-step translocations of crayfish from the south to north of Ireland was probably responsible for the observed clinal reduction of genetic diversity. There is also evidence that translocations of a limited number of animals can lead to a severe decrease in heterozygosity relative to the source population (Broders et al., 1999; Williams et al., 2002) and eventually to the complete loss of genetic variation (Grandjean et al., 2001). Thus, demographic fluctuations and human translocations could explain the absence of genetic polymorphism in some French populations sampled for this study. However, it must be kept in mind that an important role of recurrent bottlenecks does not rule out the effects of selective forces in shaping the genetic differentiation of A. pallipes populations. More field studies are now needed to gather ecological, morphological and behavioural data that will allow the detection of local adaptation as a factor in genetic structuring of this species.

\section{Conservation implications}

A basic prerequisite for managing biodiversity is the identification of population groups with independent evolutionary histories. In this study, our data from microsatellite markers provide strong evidence of historical population differentiation between northern and southern French populations of A. pallipes, which is consistent with the results from mtDNA and RAPDs (Grandjean \& Souty-Grosset, 2000; Gouin et al., 2001). Therefore, we propose that these entities should be considered as two distinct ESUs according to Moritz (1994). Despite the fact that this approach ignores adaptive differences (Crandall et al., 2000), the evidence from genetic markers, that these two groups of populations have diverged since the late Pleistocene, is a strong argument to classify them as two separate units for management objectives because they represent two evolutionarily 
distinct lineages (Avise, 1994; Moritz, 1994; Fraser \& Bernatchez, 2001).

Making further suggestions based on the sole use of neutral genetic markers would be risky at this point. However, such markers can be helpful in providing precious information about population subdivision and genetic variability that could further be used for management purposes. For example, it is clear from our study that the degradation of freshwater habitats has isolated $A$. pallipes populations, making them more sensitive to stochastic environmental changes (Lande, 1988; Sherwin \& Moritz, 2000) and more vulnerable to extinction due to loss of genetic variation (Lynch, Conery \& Burger, 1995; Frankham et al., 2002). The microsatellite markers even revealed very low levels of genetic variation in several populations, suggesting that they are particularly at risk and they should be given special attention. However, it becomes critical to develop better approaches to identify populations with high priority for conservation, which could combine data about population size and microsatellite variation as recently implemented in a freshwater mussel (Geist \& Kuehn, 2005). We also demonstrated that the genetic variation in A. pallipes populations was significantly distributed between rivers within each lineage. This result suggests that populations of each group could be managed by river basin if actions had to be taken quickly. Indeed, river basins represent an obvious management target in freshwater species because they constitute a structure in which gene flow has been confined for thousands of years. Such an approach would limit the risks of mixing genes from different pools, as suggested by Berrebi (1997).

In conclusion, this study provided new insights into the biogeography of $A$. pallipes and valuable data that can be used for its conservation in France. However, the discovery of mixed populations poses some challenges for future management strategies (Allendorf et al., 2001). More research needs to be carried out in order to evaluate the extent of genetic admixture between the Atlantic and the Mediterranean lineages and its consequences for southern populations. The analyses of genetic admixture implemented in this study must be improved because of the low polymorphism of the microsatellites and the lack of diagnostic markers. Therefore, more microsatellite markers would be needed, which would in addition allow the use of statistical tools that are more powerful analytically (Pritchard, Stephens \& Donnelly, 2000; Choisy, Franck \& Cornuet, 2004). However, this task will remain challenging as there is no record of the translocation events and potential parental populations are not known. It will also become critical to collect data concerning local adaptation in isolated populations in order to avoid any risk associated with mixing complexes of genes adapted to different environments and also to preserve the components of adaptive significance in this species (Crandall et al., 2000).

\section{Acknowledgments}

We would like to thank M. Raimond, C. Debenest, S. Patri and A. Garcia Fernandez di Castillo for technical assistance. We are grateful to the members of Conseil Supérieur de la Pêche (C.S.P.) for assistance in obtaining the crayfish samples. We also thank Paul Samollow and Julian Reynolds for critically reading a former version of the manuscript. This work was funded by the C.S.P., and was supported by a doctoral fellowship from the Région Poitou-Charentes.

\section{References}

Allendorf F.W., Leary R.F., Spruell P. \& Wenburg J.K. (2001) The problems with hybrids: setting conservation guidelines. Trends in Ecology Evolution, 16, 613-622.

Amos W. \& Harwood J. (1998) Factors affecting levels of genetic diversity in natural populations. Philosophical Transactions of the Royal Society of London, 353, 177-186.

Angers B. \& Bernatchez L. (1998) Combined use of SMM and non-SMM methods to infer fine structure and evolutionary history of closely related brook charr (Salvelinus fontinalis, Salmonidae) populations from microsatellites. Molecular Biology and Evolution, 15, 143-159.

Antunes A., Templeton A.R., Guyomard R. \& Alexandrino P. (2002) The role of nuclear genes in intraspecific evolutionary inference: genealogy of the transferrin gene in the brown trout. Molecular Biology and Evolution, 19, 1272-1287.

Attard J. \& Vianet R. (1985) Variabilité génétique et morphologique de cinq populations de l'écrevisse européenne Austropotamobius pallipes (Lereboullet 1858) (Crustacea, Decapoda). Canadian Journal of Zoology, 63, 2933-2939.

Aurelle D., Cattaneo-Berrebi G. \& Berrebi P. (2002) Natural and artificial secondary contact in brown trout 
(Salmo trutta, L) in the French western Pyrenees assessed by allozymes and microsatellites. Heredity, 89, 171-183.

Avise J.C. (1994) Molecular Markers, Natural History and Evolution. Chapman and Hall, New York.

Avise J.C. (1998) The history and purview of phylogeography: a personal reflection. Molecular Ecology, 7, 371-379.

Baillie J. \& Groombridge B. (1996) IUCN Red List of Threatened Animals. 286 p. IUCN, Gland Switzerland and Cambridge, U.K.

Barton N.H. (2000) Estimating multilocus linkage disequilibria. Heredity, 84, 373-389.

Barton N.H. \& Gale K.S. (1993) Genetic analysis of hybrid zones. In: Hybrid Zones and the Evolutionary Process (Ed. R.G. Harrison), pp. 13-45. Oxford University Press, New York.

Barton N.H. \& Hewitt G.M. (1985) Analysis of hybrid zones. Annual Review of Ecology and Systematics, 16, 113-148.

Beaumont M., Barratt E.M., Gottelli D., Kitchener A.C., Daniels M.J., Pritchard J.K. \& Bruford M.W. (2001) Genetic diversity and introgression in the Scottish wildcat. Molecular Ecology, 10, 319-336.

Belkhir K., Borsa P., Chikhi L., Raufaste N. \& Bonhomme F. (1996-2004) GENETIX 4.05, logiciel sous Windows TM pour la génétique des populations. Laboratoire Génome, Populations, Interactions, CNRS UMR 5171, Université de Montpellier II, Montpellier (France).

Bernatchez L. (2001) The evolutionary history of brown trout (Salmo trutta L.) inferred from phylogeographic, nested clade, and mismatch analyses of mitochondrial DNA variation. Evolution, 55, 351-379.

Berrebi P. (1997) Species introduction in freshwater environments: genetic impacts. Bulletin Français de la Pêche et de la Pisciculture, 344-345, 471-487.

Berrebi P., Poteaux C., Fissier M. \& Cattaneo-Berrebi G. (2000) Stocking impact and allozyme diversity in brown trout from Mediterranean southern France. Journal of Fish Biology, 56, 949-960.

Bierne N., Borsa P., Daguin C., Jollivet D., Viard F., Bonhomme F. \& David P. (2003) Introgression patterns in the mosaic hybrid zone between Mytilus edulis and M. galloprovincialis. Molecular Ecology, 12, 447-461.

Broders H.G., Mahoney S.P., Montevecchi W.A. \& Davidson W.S. (1999) Population genetic structure and the effect of founder events on the genetic variability of moose, Alces alces, in Canada. Molecular Ecology, 8, 1309-1315.

Cavalli-Sforza L.L. \& Edwards A.W.F. (1967) Phylogenetic analysis: models and estimation procedures. Evolution, 21, 550-570.
Changeux T. (2003) Changes in crayfish distribution in metropolitan France according to the national surveys performed by the Conseil Supérieur de la Pêche from 1977 to 2001. Bulletin Français de la Pêche et de la Pisciculture, 370-371, 17-41.

Choisy M., Franck P. \& Cornuet J.-M. (2004) Estimating admixture proportions with microsatellites: comparison of methods based on simulated data. Molecular Ecology, 13, 955-968.

Costello A.B., Down T.E., Pollard S.M., Pacas C.J. \& Taylor E.B. (2003) The influence of history and contemporary stream hydrology on the evolution of genetic diversity within species: an examination of microsatellite DNA variation in bull trout, Salvelinus confluentus (Pisces: Salmonidae). Evolution, 57, 328-344.

Crandall K.A., Bininda-Emonds O.R.P., Mace G.M. \& Wayne R.K. (2000) Considering evolutionary processes in conservation biology. Trends in Ecology and Evolution, 17, 390-395.

Daguin C., Bonhomme F. \& Borsa P. (2001) The zone of sympatry and hybridization of Mytilus edulis and $M$. galloprovincialis, as revealed by intron length polymorphism at locus mac-1. Heredity, 86, 342-354.

Estoup A. \& Angers B. (1998) Microsatellites and minisatellites for molecular ecology: theoretical and experimental considerations. Advances in Molecular Ecology, 306, 55-86.

Excoffier L., Smouse P.E. \& Quattro J.M. (1992) Analysis of molecular variance inferred from metric distances among DNA haplotypes: application to human mitochondrial DNA restriction data. Genetics, 131, 479-491.

Felsenstein J. (1993) PHYLIP (Phylogeny Inference Package) version 3.5.c.. Department of Genetics, University of Washington, Seattle (distributed by the author).

Fetzner J.W. \& Crandall K.A. (2001) Genetic variation. In: Chapter 10 Biology of Freshwater Crayfish, (Ed. D.M. Holdich), pp. 291-326. Blackwell Science, Oxford.

Frankham R. (1996) Relationship of genetic variation to population size in wildlife. Conservation Biology, 10, 1500-1508.

Frankham R., Ballou J.D. \& Briscoe D.A. (2002) Introduction to Conservation Genetics. Cambridge University Press, Cambridge, U.K.

Fraser D.J. \& Bernatchez L. (2001) Adaptive evolutionary conservation: towards a unified concept for defining conservation units. Molecular Ecology, 10, 2741-2752.

Fraser D.J. \& Bernatchez L. (2005) Allopatric origins of sympatric brook charr populations: colonization history and admixture. Molecular Ecology, 14, 1497-1509.

Fratini S., Zaccara S., Barbaresi S., Grandjean F., SoutyGrosset C., Crosa G. \& Gherardi F. (2005) Phylogeo- 
graphy of the threatened crayfish (genus Austropotamobius) in Italy: implications for its taxonomy and conservation. Heredity, 94, 108-118.

Garcia-Marin J.L., Utter F.M. \& Pla C. (1999) Postglacial colonization of brown trout in Europe based on distribution of allozyme variants. Heredity, 82, 46-56.

Geist J. \& Kuehn R. (2005) Genetic diversity and differentiation of central European freshwater pearl mussel (Margaritifera margaritifera L.) populations: implications for conservation and management. Molecular Ecology, 14, 425-439.

Goodman S.J. (1998) Patterns of extensive genetic differentiation and variation among European harbor seals (Phoca vitulina vitulina) revealed using microsatellite DNA polymorphisms. Molecular Biology and Evolution, 15, 104-118.

Gouin N., Grandjean F. \& Souty-Grosset C. (2000) Isolation of microsatellites in the endangered freshwater crayfish Austropotamobius pallipes and their potential use in other Decapods. Molecular Ecology, 9, 636-637

Gouin N., Souty-Grosset C., Ropiquet A. \& Grandjean F. (2002) High dispersal ability of Austropotamobius pallipes revealed by microsatellite markers in a French brook. Bulletin Français de la Pêche et de la Pisciculture, $367,681-689$.

Gouin N., Grandjean F., Bouchon D., Reynolds J. \& SoutyGrosset C. (2001) Genetic structure of the endangered freshwater crayfish Austropotamobius pallipes, assessed using RAPD markers. Heredity, 87, 80-87.

Gouin N., Pain S., Reynolds J., Souty-Grosset C. \& Grandjean F. (2003) Origin and colonization history of the white-clawed crayfish Austropotamobius pallipes in Ireland. Heredity, 91, 70-77.

Grandjean F. \& Souty-Grosset C. (2000) Mitochondrial DNA variation and population genetic structure of the white-clawed crayfish, Austropotamobius pallipes pallipes. Conservation Genetics, 1, 309-319.

Grandjean F., Gouin N., Souty-Grosset C. \& DieguezUribeondo J. (2001) Drastic bottlenecks in the endangered crayfish species, Austropotamobius pallipes, in Spain with inference to its colonization history. Heredity, 86, 431-438.

Grandjean F., Harris D.J., Souty-Grosset C. \& Crandall K.A. (2000) Systematics of the European endangered crayfish species Austropotamobius pallipes (Decapoda: Astacidae). Journal of Crustacean Biology, 20, 523-529.

Grandjean F., Souty-Grosset C., Raimond R. \& Holdich D.M. (1997) Geographical variation of mitochondrial DNA between populations of the white-clawed crayfish Austropotamobius pallipes. Freshwater Biology, 37, 493-501.

Grandjean F., Momon J. \& Bramard M. (2003) Biological water quality assessment of the white-clawed crayfish habitat based on macroinvertebrates communities: usefulness for its conservation. Bulletin Français de la Pêche et de la Pisciculture, 370-371, 115-125.

Guo S.W. \& Thompson E.A. (1992) Performing the exact test of Hardy-Weinberg proportion for multiple alleles. Biometrics, 48, 361-372.

Hardy O.J. \& Vekemans X. (2002) SPAGeDI: a versatile computer program to analyse spatial genetic structure at the individual or population levels. Molecular Ecology Notes, 2, 618-620.

Hardy O.J., Charbonnel N., Fréville H. \& Heuertz M (2003) Microsatellite allele sizes: a simple test to assess their significance on genetic differentiation. Genetics, 163, 1467-1482.

Hartl D.L. \& Clark A.G. (1997) Principles of Population Genetics. 3rd edn. Sinauer Associates, Sunderland, MA.

Hébert C., Danzman R.G., Jones M.W. \& Bernatchez L. (2000) Hydrography and population genetic structure in brook charr (Salvelinus fontinalis, Mitchill) from eastern Canada. Molecular Ecology, 9, 971-982.

Hedrick P.W. (2000) Applications of population genetics and molecular techniques to conservation biology. In: Genetics, Demography and Viability of Fragmented Populations. (Eds A.G. Young \& G.M. Clarke), pp. 113125. Cambridge University Press, Cambridge, UK.

Koskinen M.T., Nilsson J., Veselov A., Potutkin A.G., Ranta E. \& Primmer C.R. (2002) Microsatellite data resolve phylogeographic patterns in European grayling, Thymallus thymallus, Salmonidae. Heredity, 88, 391-401.

Lande R. (1988) Genetics and demography in biological conservation. Science, 241, 1455-1460.

Largiadèr C.R., Herger F., Lörtscher M. \& Scholl A. (2000) Assessment of natural and artificial propagation of the white-clawed crayfish (Austropotamobius pallipes species complex) in the Alpine region with nuclear and mitochondrial markers. Molecular Ecology, 9, 25-37.

Lörtscher M., Stucki T.P., Claluna M. \& Scholl A. (1997) Phylogeographic structure of Austropotamobius pallipes populations in Switzerland. Bulletin Français de la Pêche et de la Pisciculture, 347, 649-661.

Lugon-Moulin N., Brünner A., Wyttenbach J., Hausser J. \& Goudet J. (1999) Hierarchical analyses of genetic differentiation in a hybrid zone of Sorex araneus (Insectivora: Soricidae). Molecular Ecology, 8, 419-431.

Lynch M., Conery J. \& Burger R. (1995) Mutation accumulation and the extinction of small populations. The American Naturalist, 146, 489-518.

Machino Y., Füreder L., Laurent P.J. \& Petutchnig J. (2004) Introduction of the white-clawed crayfish Austropotamobius pallipes in Europe. Berichte des Naturwissenschaftlich-Medizinischen Vereins in Innsbruck, 91, 187-212. 
Michalakis Y. \& Excoffier L. (1996) A generic estimation of population subdivision using distances between alleles with special reference to microsatellite loci. Genetics, 142, 1061-1064.

Moritz C. (1994) Defining evolutionarily significant unit's for conservation. Trends in Ecology and Evolution, 9, 373-375.

Nagel K.O. (2000) Testing hypotheses on the dispersal and evolutionary history of freshwater mussels (Mollusca: Bivalvia, Unionidae). Journal of Evolutionary Biology, 13, 854-865.

Nei M. (1978) Estimation of average heterozygosity and genetic distance from a small number of individuals. Genetics, 89, 583-590.

Neveu A. (2000) Etude des populations d' Austropotamobius pallipes (Crustacea, Astacidae) dans un ruisseau forestier de Normandie. II. Répartition en fonction de la structure des habitats: stabilité et variabilité au cours de cinq années. Bulletin Français de la Pêche et de la Pisciculture, 356, 99-122.

Poteaux C., Bonhomme F. \& Berrebi P. (1999) Microsatellite polymorphism and genetic impact of restocking in Mediterranean brown trout (Salmo trutta L.). Heredity, 82, 645-653.

Pritchard J.K., Stephens M. \& Donnelly P. (2000) Inference of population structure using multilocus genotype data. Genetics, 155, 945-959.

Raymond M. \& Rousset F. (1995) GENEPOP (Version 1.2): population genetics software for exact tests and ecumenicism. Journal of Heredity, 86, 248-249.

Rice W.R. (1989) Analysing tables of statistical tests. Evolution, 43, 223-225.

Ryder O.A. (1986) Species conservation and systematics: the dilemma of subspecies. Trends in Ecology and Evolution, 1, 9-10.

Santucci F., Iaconnelli M., Andreani P., Cianchi R., Nascetti G. \& Bullini L. (1997) Allozyme diversity of European freshwater crayfish of the genus Austropotamobius. Bulletin Français de la Pêche et de la Pisciculture, 347, 663-676.
Schneider S., Roessli D. \& Excoffier L. (2000) Arlequin version 2000: a software for population genetics data analysis. Genetics and Biometry laboratory. University of Geneva, Switzerland. http://anthropologie.unige.ch/ arlequin.

Sherwin W.B. \& Moritz C. (2000) Managing and monitoring of genetic erosion. In: Genetics, Demography and Viability of Fragmented Populations (Eds A.G. Young \& G.M. Clarke), pp. 9-34. Cambridge University Press, Cambridge, UK.

Souty-Grosset C., Grandjean F., Raimond R., Frelon M., Debenest C. \& Bramard M. (1997) Conservation genetics of the white-clawed crayfish Austropotamobius pallipes: the usefulness of the mitochondrial DNA marker. Bulletin Français de la Pêche et de la Pisciculture, 347, 677-692.

Trontelj P., Machino Y. \& Sket B. (2005) Phylogenetic and phylogeographic relationships in the crayfish genus Austropotamobius inferred from mitochondrial COI gene sequence. Molecular Phylogenetics and Evolution, 34, 212-226.

Trouilhé M.C., Ricard F., Parinet B., Grandjean F. \& Souty-Grosset C. (2003) Management of the whiteclawed crayfish (Austropotamobius pallipes) in Western France: abiotic and biotic factors study. Bulletin Français de la Pêche et de la Pisciculture, 370-371, 97114.

Ward R.D., Woodwark M. \& Skibinski D.O.F. (1994) A comparison of genetic diversity levels in marine, freshwater and anadromous fish. Journal of Fish Biology, 44, 213-232.

Weir B.S. \& Cockerham C.C. (1984) Estimating F-statistics for the analysis of population structure. Evolution, 38, 1358-1370.

Williams C.L., Serfass T.L., Cogan R. \& Rhodes O.E. (2002) Microsatellite variation in the reintroduced Pennsylvania elk herd. Molecular Ecology, 11, 12991310.

(Manuscript accepted 3 April 2006) 


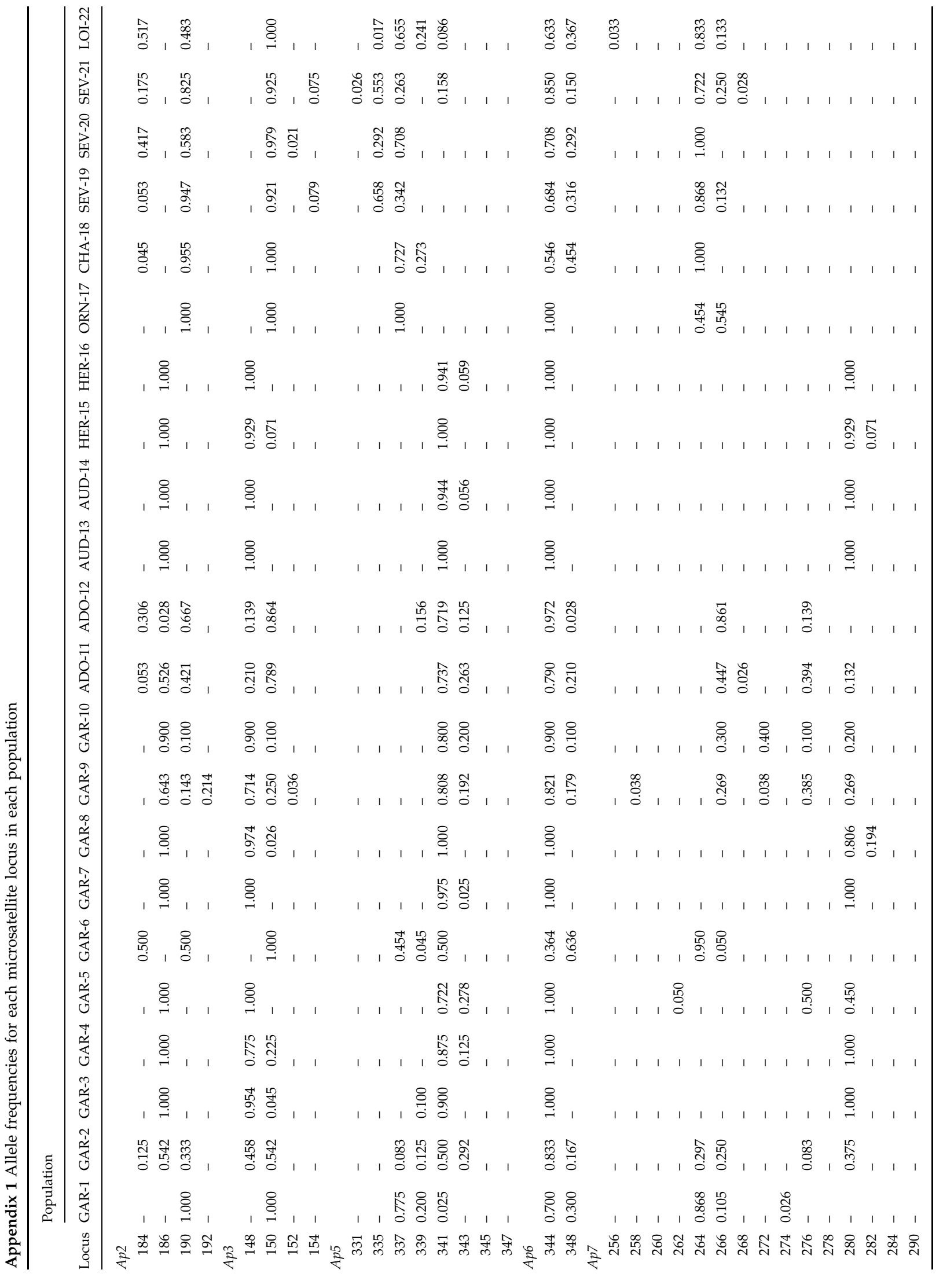




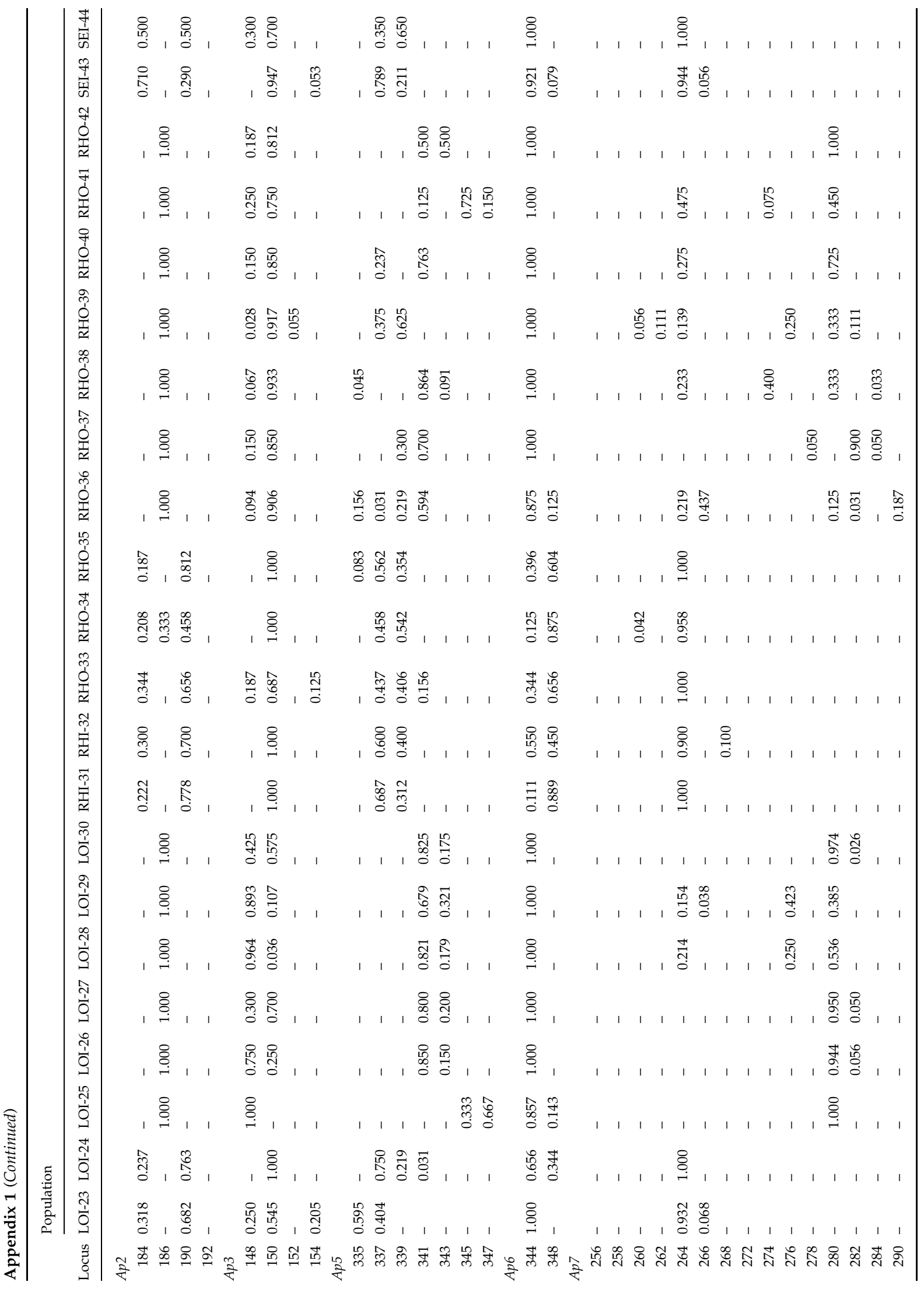

